\title{
THE EFFECT OF EDUCATIONAL BACKGROUND ON POLITENESS AMONG THE STUDENTS OF STAIN JURAI SIWO METRO
}

\author{
Ahmad Subhan Roza \\ Institut Agama Islam Negeri Metro, Lampung \\ E-mail: ahmadsubhanroza@gmail.com
}

\begin{abstract}
Humans are social creatures who need other humans to fullfil their needs, communication and interaction have a crucial role to fullfil those needs. In order to the communication process can proceed smoothly, then at least human need to speak in polite in the communication. Religious norms and the community shows that politeness is necessary to properly maximized. Politeness in the relating of the Holy Qur'an about pronunciation, gestures and vocabulary was polite and adapted to the circumstances (environment). In social life, politeness is usually used to show respect for older people, but it would be better also if used against a fellow or a younger person. Politeness will minimize conflict and hostility. Because of it, the institution is one way of language education. STAIN Jurai Siwo Metro is an Islamic institution, that students have many educational backgrounds and is so different each other. Based on the mapping carried out showed that students of English Department Program, the majority coming from Senior High School (SMA). This study aims to determine the reality of politeness and influence of the educational background to the student politeness in English Study Program STAIN Jurai Siwo Metro. The method used in this research is quantitative descriptive, where interviews, observation and documentation used by researchers in collecting and obtaining data. From the data obtained show that the reality of politeness students have to realize elements of politeness. Furthermore, based on analysis of the data also showed that educational background gives affect student in politeness.
\end{abstract}

Keywords : Educational background, Speak in polite.

\section{INTRODUCTION}

Humans are social creatures who need other humans to fulfill their needs. These needs encourage the process of communication among people in building relationships with others. It requires a language as a tool to communicate. In order to the communication process can proceed smoothly, then at least human need to speak in polite in the communication.

The Holy Qur'an was revealed to mankind as a guide for human life. As a guide, the Holy Qur'an itself uses understandable language for humans though having a high literary level. We can see how the Holy Qur'an gives explanations 
on each teaching in a language that is acceptable for humans and can thrill readers and listeners.

The Holy Qur'an itself has given the guidance to communicate, especially when speaking with humans. In terms of communication, Islam places emphasis on social values, religion, and culture. Politeness in the relating of the Holy Qur'an about pronunciation, gestures and vocabulary was polite and adapted to the circumstances (environment), as they are implied in the following verse, which means: ".And be moderate in your pace and lower your voice; indeed, the most disagreeable of sounds is the voice of donkeys." (QS. Lukman: 19). The above verse implies that the Holy Qur'an encourages people to speak politely in conveying his thoughts. Politeness is a depiction of a man who has high personality, whereas people who are not polite are equated like animals.

Based on the paragraph above, politeness is a behavior that indicates a person towards others either in speaking or behaving. According to Keith Allan (2006:1) politeness is usually used to show respect for older people, but it would be better also if used against a fellow or a younger person.

Every person has a varying level of politeness because politeness is strongly influenced by family and environmental factors. Politeness is not only present because of their feeling of wanting to show respect to others. Sometimes it comes for their demands. Examples subordinates should always be obedient to his superiors, students to lecturers, brother sister-level and other levels.
Politeness is usually expressed through body language (facial expression) person when talking. Whether he smile or frown also shows how the attitude of respect against another person. Moreover, Francesa Bargiela-Chiappini (2002:1455) states that politeness is not only shown through body language when speaking, but also through the intonation of someone while speaking.

In conducting daily activities, people will always meet and interact with others. In interacting with others, humans use language as a communication media. In the normal communication, each of the parties involved, namely between speakers and listeners will always strive to convey his words effectively and efficiently.

Based on preliminary observations that researchers did among students, not only students of STAIN Jurai Siwo Metro graduated from Madrasah Aliyah or Religious education, but also there are many who graduated from SMA, STM and SMEA. The vocabulary of politeness which is used by the student in communicating with lecturers, students with students and students with the employees are very varied, and most of them have not used the principles of politeness in communication or conversational maxim. In this case there are differences in the perception of politeness among students, lecturers, and employees. The students' view with different educational backgrounds to politeness is concerned with pragmatic terms, while according to lecturers and 
employees politeness are more likely normative.

Therefore, related to the problem of politeness/language decency which has been described above is based on the concept of cooperation conversational maxim and the importance of politeness/decency in speech, researcher tried to investigate how the reality of the effect of educational backgrounds to politeness in speaking students of STAIN Jurai Siwo Metro.

\section{THEORETICAL REVIEW Definition of Politeness}

Lakoff (1990:32) in Brown and Levinson defines politeness as a form of conflict prevention. It is undeniable that the conflict which is springs from a simple problem is lost its sense of mutual respect. If it is associated with the study of pragmatics, politeness has an important role in minimizing the forms of confrontation and conflict.

Furthermore, Leech (in Wijana, 1996) revealed that the longer the person's speech, the greater person's desire to be polite to his interlocutor. Similarly, Richard J.Watts (1992:43) states that the utterances are expressed indirectly usually more polite than the utterances expressed directly.

While Grice (1975:89) added that modesty is a manifestation of respect, appreciation and identity of a person. Politeness is a behavior that is expressed in a good way or ethical. Politeness is a cultural phenomenon, so what was considered polite by one culture may not be the case with other cultures. The purpose of politeness, including linguistic politeness, is making the Interactional atmosphere.

Polite is often superficially interpreted as an action which is just civilized only, but more important meaning obtained from modesty is the missing link between the principles of cooperation with the problem of how to associate the power with meaning.

Granting selection will influence the level of politeness. The more likely answer "no" is given, then the utterances was more polite. Brown and Levinson (2003:2) defines Positive politeness aims to save by applying closeness and solidarity, usually in friendship or companionship, make other people feel comfortable and emphasize that the two parties (speakers and listeners) have the same goal.

Based on the above statement, it can be concluded that the indication of someone's politeness/modesty can be seen from the speech delivered in speaking and how someone was behave when communicating with others.

\section{Language Politeness Theory}

Theories about language modesty that is mostly referred by linguists and pragmatic filed by Brown and Levinson. Both the linguist assumes that every individual from the society have the concept of face and every individual realize that it is owned by other citizens. Every human when interacting with others always maintain and cooperate to respect each other. Nadar (2009:67) has a concept that everyone has this face is universally valid though any utterances that can threaten, destroy, 
or reduce the respect for a person's face is different from one culture to another. Modesty or linguistic politeness is specifically aimed at the maintenance of the face by everyone involved in a communication, so that no one felt her face smudged (Goffman in Arisnawati, 2012).

\section{Principle of Politeness}

Modesty/politeness generally associated with the relationship between two participants who can be called as 'self' and 'others'. The views of politeness within pragmatics study are elaborated by some experts.

Among them are Leech, Robin Lakoff, Bowl and Levinson. The principle of modesty has several maxims; those are tact maxim, generosity maxim, approbation maxim, modesty maxim, agreement maxim, and sympathy maxim. Wijana (1996:57) the principle politeness is related to two participants of the conversation, self and other. Self is speakers, and others are opponents said.

Furthermore, Leech as quoted by Chaer proposed the theory of politeness by politeness principles, which is explained to be maxim. The six maxims are as follows.

\section{Tact Maxim}

The basic idea of the tact maxim in the politeness principle is that the participants of substitutions should stick to the principle to reducing own gain and maximizing profit in the activities of the other speaks. The speakers were adhering and implementing the tact maxim will be regarded as a polite person.

\section{Generosity Maxim}

By generosity maxim, participants substitutions are expected to respect others. Respect to others will happen if people can reduce profits for himself and maximize profits for others.

\section{ApprobationMaxim}

The approbation maxim described that a person will be regarded polite when in speaking always tries to give awards to others. With this maxim, it is expected that the participants of substitutions are not mutually mocking, deriding each other, or the despise each other. Participants said that often mock the other speaker in the speaking activity will be regarded as a impolite on. It is said that because the act of mocking is an act of disrespectful to others.

\section{Modesty Maxim}

In the modesty maxim, participants are expected to be humble by reducing the praise on self. People will be regarded arrogant and supercilious careful if in speaking activities always praise and favor self.

\section{Agreement Maxim}

Within this maxim it is expected that participants said the participants are able to establish the suitability or agreement in speaking activities. If there is an agreement or suitability between speaker and listener in speaking activities, each one of them can be regarded as a polite. 


\section{Sympathy Maxim}

Sympathy maxim is requiring all participants of substitutions to maximize the sympathy and minimize the sense of antipasti to the other speaker.

\section{Politeness Scale}

At least there are three kinds of measure of the politeness scale that is until now widely used as a basic reference in the study of politeness. The three scales include:

\section{Leech Politeness scale}

According to Richard J.Watts (1992:57) in the Leech politeness model, every interpersonal maxim can be used to rank the linguistic politeness. The following Leech politeness scale:

1. Cost benefit scale: Representing the cost or benefit of an act to the speaker and hearer

Referring to the size of losses and gains which caused by a speech act in a substitutions. The more the self-injurious utterances of speakers will be considered polite the speech. Vice versa, the more speech benefit for speaker himself will be deemed impolite the speech. If it is seen from the perspective of the hearer can be said that the more profitable of the hearer, will be deemed not his polite speech.

2. Optimality scale: Indicating the degree of choice permitted to speakers and / or hearer by a specific linguistic act

Pointing to many or least options which are presented by the speaker to the hearer in speaking activities. The more substitutions that allow the speaker or hearer to determine which options are numerous and freely, it will be considered more polite the utterances.

3. Indirectness scale: Indicating the amount of inference required by the hearer in order to establish the intended speaker meaning Pointing to the direct and indirect rank which is purpose from speech, the more direct speech will be considered the more impolite the speech.

4. Authority scale: representing the status of the relationship between speaker and hearer

Pointing to the relationship of social status between speaker and hearer involved in substitutions, the farther the distance of social rank between the speakers with the hearer, the speech used will tend to be more polite.

5. Social distance scale: Indicating the degree of familiarity between the speaker and the hearer Pointing to the relationship of social rank between speaker and hearer is involved in substitutions. There is a tendency that the closer the social rank of both will be the more impolite the speech.

\section{The Brown-Levinson politeness scale}

According to Brown and Levinson (2003:76), there are 3 politeness scale:

1. Scale ratings of social distance between speaker and hearer.

Many parameters are determined by differences in age, gender, and socio-cultural background. 
2. Scale ratings of social status between speaker and hearer Based on the asymmetric position between speaker and hearer can be said to be based on the speaker and hearer relative power (rated power or power rating).

3. Rating Scale Speech

This is called by rating or full rank is the degree of imposition associated with the required expenditure of goods or services based on the relative position of the speech acts with other speech acts.

\section{The Concept of Speaking Modesty Speak}

Why does one have to familiarize himself polite language, either orally or in writing to another person. Brown and Levinson (2003: 135) states there are several reasons, among others:

1. Respect for others

By using polite language, it means someone has demonstrated the attitude of appreciation to others and treat human as human should.

2. Harmonious

Harmonious life among individuals in the community will be difficult to achieve if the members of the community have no ethics and manners speak. Cases of fights between individuals (one by one), intergroup, or even between villages often occurs because impolite in the language.

3. Mutual understanding

Polite language can also avoid misunderstandings between people who conduct the communication.

\section{Speak Courtesy Education in Campus}

Politeness language is closely related to a culture. Both of these cannot be separated from each other. A reflection of a culture is language and vice versa, the culture is values or principles that can be true in the community of speakers of a language, and can be a guide in interacting and communicating. For example, student speaking culture.

In the context of creating a peaceful society, the planting of politeness pursued through education at the Institute of Education. Universities are educational institutions, i.e. the place where education takes place. Educational School is a learning process or the process of educative communication between teachers and students. Meanwhile, as a social institution, the Campus has a role to guide and direct the students to know, understand and actualize lifestyle prevailing in society. Moral values and ethics that developed and maintained politeness in society that introduced and training to students so that they can implement them in everyday life. Moral and ethical values of modesty have become a reference for students can do, either in the form of words and deeds.

Today if you see discovery language among the students, the vocabulary of politeness that is used by the student in communicating with lecturers, vocabulary ordinary or natural, is the vocabulary of the language used by the student in communicating with other students, and the vocabulary of the language is not polite in communication students with close friend. Moreover, in some 
regions in Indonesia, there are still many students who communicate with abusive language, either by friends and lecturers.

There are differences in perception of politeness among students, faculty, and employees. Student views towards politeness is concerned with in terms of pragmatic, while according to faculty and staff politeness is more likely to normative, among others, truth, honesty, justice, goodness, straight, smooth, polite, proper, approbation, solemn, optimism, wonderful fun, logical , fluent, bright, right, touches the heart, harmony, impressive, quiet, effective, soft, generous, gentle, and humble.

Lecturer as an educator in this regard has an important role to educate the students in order to have the language skills to whoever invited mannered communication. To familiarize polite language may be a bit difficult for the students that in fact were never taught manners at home speaking accustom.

Public education was directing towards the realization of the goal of human personality. Human figure has a real personality is revealed through the language of the display. Therefore, a language in public education is a very important aspect and stands out and become the personality traits that seem to surface. Politeness was also later became a benchmark of education. Brown and Levinson (2003: 54) state the level of politeness someone is usually directly proportional to the level of one's education.

The Qur'an was revealed to mankind as a guide for human life. As a guide, the Qur'an itself uses language understandable humans despite having a high literary level. The Qur'an itself has provided guidance to communicate, especially to speak to humans. In terms of communication, Islam places emphasis on social values, religion, and culture. Politeness in the relating of the Holy Qur'an about pronunciation, gestures and vocabulary was polite and adapted to the circumstances (environment) speakers, as suggested in the following verse: "..And be moderate in your pace and lower your voice; indeed, the most disagreeable of sounds is the voice of donkeys. "(QS. Lukman: 19).

Softening the sound in the above verse implies a way of delivering a phrase that was not harsh, so that the mission can be delivered not only understandable, but also can be absorbed and internalized its meaning. Selection of the right word is also noteworthy things in communicating. Talking to older people should use language that is more polite and courteous because governance of the talk with the younger crowd. The parable of the poor sound on sound described Himar because these animals are well known among the Arabs is animals that sound ugly and unpleasant on the ear. In another verse the Qur'an says and the meaning is the following

"And your Lord has decreed that you not worship except Him, and to parents, good treatment. Whether one or both of them reach old age [while] with you, say not to them [so much as], "uff," and do not repel them but speak to them a noble word." (QS. Al-Isra: 23). 
In this verse politeness is related to people talk. Discussion mannered is appropriate talks with people, situations and environmental conditions talk.

\section{RESULTS AND DISCUSSION}

In general, the purpose of this research is to describe the realization of politeness students and the influence students' educational backgrounds of English Education toward politeness. Researcher chooses the fifth semester students because it feels quite representative in this research, which linked her with politeness. The researcher has pointed out earlier that the cultivation of politeness can be reached through education.

Firstly, the researcher describes the results and discussion about the politeness of students, along with the principles of politeness by maxims of politeness by Leech in Chaer. Speech politeness students at State Islamic Institute (STAIN) Jurai Siwo Metro found 23 speeches. Utterance of politeness students with students at STAIN Jurai Siwo Metro consists of 19 utterances, utterance to professors recorded five utterances which includes six maxims of politeness by Leech, namely are tact maxim, generosity maxim, approbation maxim, modesty maxim, agreement maxim, and sympathy maxim. Data presented by the table below

Table. 1 Results Reality Politeness Students Speak

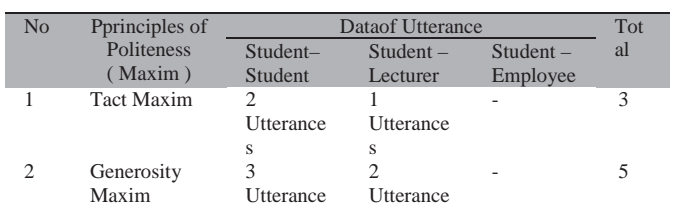

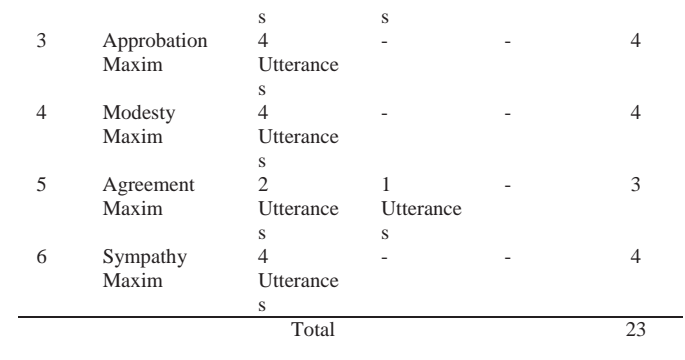

In answering the above problem formulation, researcher used the above indicators and gave questionnaires to 39 participants of the studies.

\section{Chart 2. Research Participants}

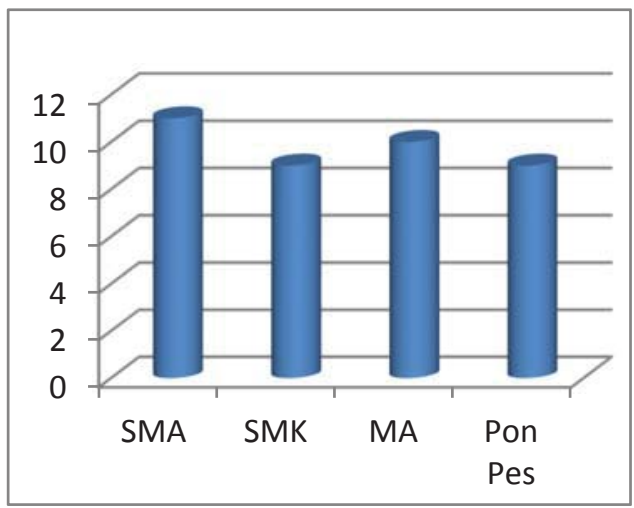

11 of 39 participants are graduated from Senior High School, the graduated MA as many as 10 people. While the vocational school graduates and Islamic Boarding School respectively 9 people. The participants were given a questionnaire. Filling the questionnaire was carried out in the Laboratory of First Floor.

The results are categorized into four sessions and presented through charts and tables. First, the politeness from social norms. Second, Fulfillment Maxim. Third, Speech Acts and the fourth is a student perceptions about education 
politeness. The results elaborated as follows.

Figure 3. Linguistic Politeness on Social Norms

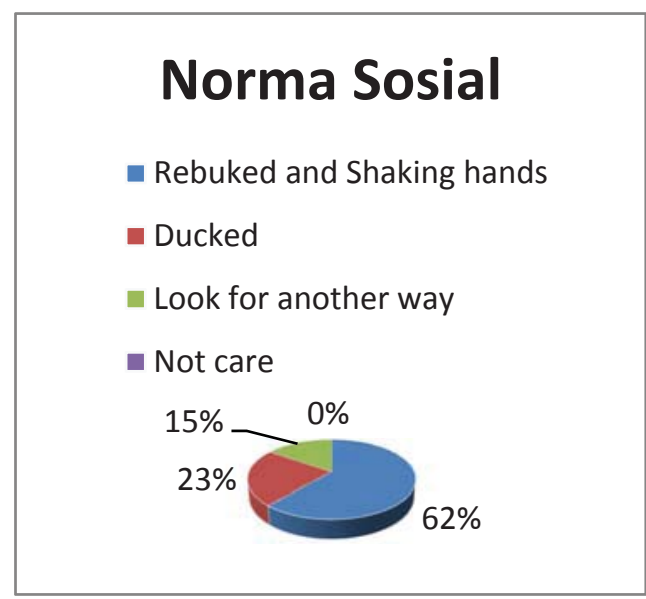

The chart draws the answers from research participants, the questions in the questionnaire is "if you look at your faculty, staff and OB walking towards you, what are you doing?". The majority of research participants (62\%) answered rebuked and shaking hands, 23\% gave the answer ducked when they meet with lecturers, while $15 \%$ look for another way. This means that the students see the norms that apply in the society speech in STAIN Jurai Siwo Metro. Social norms when the younger one / learners can honor the teachers, by reprimanding (smile, say hello, niceties) and shaking hands, while the older love the younger. From these activities will show a harmonious speech community.

Table 4.

\begin{tabular}{lllll}
\multicolumn{1}{c}{ Responden } & SMA & MA & SMK & $\begin{array}{l}\text { Pon } \\
\text { Pes }\end{array}$ \\
$\begin{array}{l}\text { Rebuked and } \\
\text { Shaking Hands }\end{array}$ & 9 & 7 & 5 & 3 \\
$\begin{array}{l}\text { Ducked } \\
\text { Look for another }\end{array}$ & - & 2 & 4 & 3 \\
way & 11 & 10 & 9 & 9 \\
Total & & & & \\
\hline
\end{tabular}

Second the Fulfillment Maxim, aspects are taken into account in the session is the fulfillment of the four maxims speech. Such speak is not physically disabled, speak according to the available evidence, choose the term were polite and spoke with informative. The results refer to the answers of the research participants from questions in the questionnaire.

\section{Chart 5. Fulfillment of Maxim}

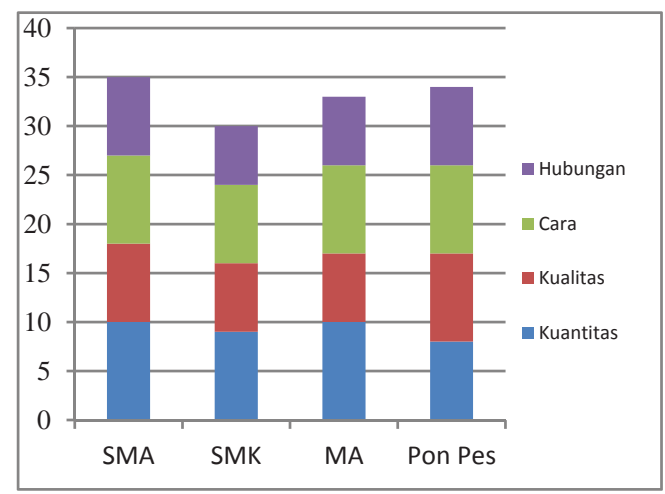

The above data shows that the fulfillment of maxim cooperation student feels quite good. The educational background of high school, for example, 10 of 11 respondents meet the maxim of quantity, 8 meets the maxim of quality, maxim 9 people watched the way and 8 meet maxim the relationship. Then, a graduate of Vocational High School (SMK) all respondents meet the maxim of quantity, quality maxim noticed 7,8 and 6 realize the maxim way the maxim maximize the relationship. The above data also presents the results of the fulfillment of maxim by graduates Madrasah Aliyah, data gathered from graduates of MA. MA is all respondents met the criteria 
maxim of quantity, quality maxim maximizing 7, 9 out of 10 noticed maxim way, then 7 participants from MA meets maxim the relationship. As for the graduated of Pesantren, 8 meet the maxim of quantity, quality maxim 9, 9 respondents maxim way while 8 from 9 respondents meets maxim relationship.

Figure below shows the Speech Act students based on educational background. The data below refers to the results of a questionnaire, in which participants were given question according to indicators of politeness namely: style of speech, gestures, gaze etc.

Figure 6. Percentage Speech Acts Student

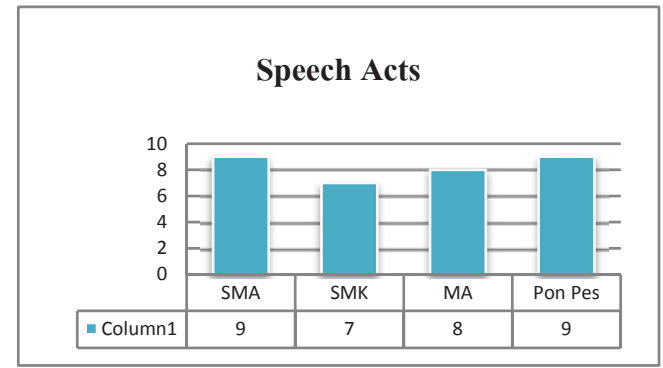

Graduated of Islamic Boarding School have a high level of speech acts than graduates from other educational institutions. The majority of respondents admitted that they will stare at the speaker or the speaker, did not see the object to another

"My reason why I had to stare at the speaker gently when communication is: I want to reward those who are interacting with me, and would lower the intonation of my voice so as not to offend them." AS 13106647 (Pon Pes)

Vocational High School graduate is prepared to be ready to work, jobs and the world of work after they graduate. The school environment introduces the workplace atmosphere to the learners. As what was said by the respondents above, they have been taught how to speak, communicate and interact with others politely. It aims to train and familiarize the learners in vocational communicate well with colleagues.

\section{CONCLUSION}

Based on the results of research and discussion, it can be concluded that the study of students' politeness at STAIN Jurai Siwo Metro found 23 utterances containing six maxim that tact maxim, generosity maxim, approbation maxim, modesty maxim, agreement maxim, and sympathy maxim. In the speech 23 speech politeness comprise 19 students and four students with speech politeness students and lecturers. Of the 23 utterances by both the students and students and students and lecturers, all of which embody the principles of decency. It can be deduced that the reality in the field is a student will uphold maxim politeness.

The influence of politeness was seen speaking students from the four indicators, namely social norms, Fulfillment maxims, Speech Acts and the implications of educational backgrounds. Once researcher gets the data, then the test data through SPSS, the results obtained are as follows:

\section{Social Norms}

Data in this session drawn from the discussion data were further tested through SPSS, its results are a). Background education of high school, the result is greater than the table (1.344> 0.681). b). Graduated 
of SMK in its relation to social norms which showed positive results (1.964> 0.68). c). Similar results were also found in MA (1.796) and Pondok Pesantren (1.732), indicating the data is greater from table. From all the above data, researcher concluded that the HA is accepted while HO rejected.

\section{Fulfillment Maxim}

In calculating the fulfillment of the four maxim final data by the student, the data obtained as follows: Background SMA (18.28), SMK (11.61), Madrasah Aliyah had a score of 11.00, while the Islamic Boarding School 29.45. Can be seen in all of the above data is greater than 0.681 . Thus, HA is positive / received.

\section{Speech Acts}

Fulfillment of speech acts refer to the questions in the questionnaire that has been given. The results are as follows: SMA $(1.57>0.681)$, SMK $(1.80>0.681)$, MA $(1.28>0.681)$ and d.) Islamic Boarding School 1.00> 0.681 . All data above states that HA is positive.

4. Implications of educational backgrounds

All data was related with positive implications stating educational background. Data as follows:
a. SMA 3.66>0.681
b. SMK 3, 00>0.681
c. MA $1.66>0.681$
d. Pon Pes 1.25>0.681

The results of the data obtained show that the HA on the implications of educational background was positive/ received.
After reading all the data above which have been obtained, the researcher concludes that HA (there is the influence towards educational background of students' politeness of English Education) is accepted, whereas HO (there is no influence towards educational background of students' politeness English Education) is rejected.

The results of this research aim to expand the repertoire of discussion of politeness and speech acts of the students. As a young scientist, politeness and speech acts will show the quality of the speakers themselves. Through this study, researcher hope that students in STAIN Jurai Siwo Metro will have paid more attention and realize politeness on campus, considering college as a place to gain knowledge is Islamic institute.

\section{REFERENCES}

$$
\begin{aligned}
& \text { Arisawati, N. 2012. Strategi } \\
& \text { kesantunan tindak tutur } \\
& \text { penolakan dalam bahasa } \\
& \text { Makassar. Sawerigading, }
\end{aligned}
$$

Brown and Levinson, 2003,Politness,Cambridge: University Press

Chaer, Abdul. Agustina, Leonie. 2004. Sosiolinguistik:

Perkenalan Awal. Jakarta: Rineka Cipta.

Cutting, Joan. 2002. Pragmatics and Discourse: A Resource Book for Students. New York: Routledge 
Daniel Z.Kadar, 2011, Politeness in East Asia,UK: Cambridge University Press

John W. Creswell,2003,Research Design: Qualitative, Quantitative, and mixed Methods Approach. New Delhi: Sage Publication

Leech, Geoffrey. 1991. Principle of Pragmatics. London: Longman
Moleong, L. J.2001,Metologi Penelitian Kualitatif. Bandung: Remaja Rosydakarya,

Nadar, F.X., 2009,Pragmatik dan Penelitian Pragmatik. Yogyakarta: Graha Ilmu.

Noeng Muhadjir. Metodologi Penelitian Kualitatif. Edisi IV. Yogyakarta: Rake Sarasin, 2000

Nurul Zuriah, 2009, Metodologi Penelitian Sosial dan Pendidikan, Jakarta, Bumi Aksara

Pedoman Penulisan Karya Ilmiah, 2015, STAIN Jurai Siwo, Metro,

Richard J.Watts, 1992, Politness in Language, New York, Mouten de Gruyter

Rahardi, Kunjana. 2005. Pragmatik Kesantunan Imperatif Bahasa Indonesia.
Sara Mills, 2003, Gender and Politness, Cambridge, University Press

Sumitro, 1998, Pengantar Ilmu Pendidikan, Yogyakarta: IKIP Yogyakarta

Suherman. 2008. Prinsip Kerjasama, Kesopanan dan Ironi dalam masyarakat

Jepang: Sebuah Tinjauan dari Dimensi Sosiopragmatis. Jurnal LITE, 4(1).

Wijana, I Dewa Putu. 1996. Dasardasar Pragmatik. Yogyakarta: Penerbit Andi Yule, George. 1996 